\title{
PEMBENTUKAN KEPRIBADIAN MUSLIM DALAM PERSPEKTIF FILSAFAT PENDIDIKAN ISLAM
}

\author{
Ainun Mardia Harahap \\ Sekolah Tinggi Agama Islam Negeri Mandailing Natal \\ Email: ainunmardia1666@gmail.com
}

\begin{abstract}
Abstrak
Pembentukan kepribadian muslim adalah membiasakan diri untuk menjadi Muslim sejati yang mempunyai kepribadian Islami yang sesuai dengan tuntutan dan tuntunan syariat Islam. Oleh karena itu setiap pribadi Muslim diharapkan dapat mendidik serta membiasakan diri pribadi khususnya, keluarga terdekat serta umat muslim pada umumnya agar dapat mengamalkan berbagai bentuk latihan dan pendidikan agar tercipta kepribadian Muslim Ummah yang betul betul sesuai dengan ajaran Islam. Dengan demikian akan tercipta keluarga, masyarakat serta bangsa yang sejahtera, baldatun thayyibatun wa rabbun ghafur.
\end{abstract}

Keywords: Muslim personality, philosophy of Islamic education

\begin{abstract}
The formation of a Muslim personality is to get used to being a true Muslim who has an Islamic personality that is in accordance with the demands and guidance of Islamic shari'a. Therefore every Muslim person is expected to be able to educate and familiarize himself especially, the closest family and Muslims in general in order to practice various forms of training and education in order to create a Ummah Muslim personality that is truly in accordance with Islamic teachings. Thus will create a prosperous family, community and nation, baldatun thayyibatun wa rabbun ghafur.
\end{abstract}

Kata Kunci: Kepribadian Muslim, Filsafat Pendidikan Islam 


\section{Ainun Mardiah Harahap}

\section{Pendahulun}

Manusia adalah makhluk ciptaan Allah yang paling sempurna dibandingkan dengan makhluk yang lainnya. Konsepsi Islam tentang esensi manusia sebagai makhluk ciptaan yang paling sempurna terdapat dalam surat al-Tin ayat 4 berbunyi:

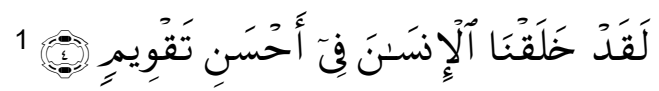

Artinya: Sesungguhnya Kami telah menciptakan manusia dalam bentuk yang sebaik-baiknya.

Manusia sebagai makhluk ciptaan yang paling sempurna dapat dilihat dari dua segi, fisik dan fsikis. Dari segi fisik, susunan anggota tubuh manusia merupakan susunan yang didesain sedemikian rupa sehingga menjadikan manusia sempurna, misal otak adalah bagian tubuh yang paling mulia ditempatkan pada posisi tertinggi, berbeda dengan binatang yang otaknya sama rata dengan punggungnya. Ini salah satu bukti kesempurnaan manusia dibandingkan makhluk lainnya. Dari segi fsikis manusia mampu berfikir, mempertimbangkan, dan menggunakan akalnya dengan baik.Di samping itu manusia adalah makhluk yang dilengkapi dengan akal dan nafsu.

Di dalam diri manusia terdapat potensi baik dan potensi buruk, sifat-sifat Ilahiyah dan sifat-sifat Syaithoniyah, yang kedua sifat ini masih berbentuk bahan mentah yang harus diolah. Jika sifat Syaithoniyah lebih dominan berkembang, maka akan muncul pribadi yang buruk, jika sifat Ilahiyah dipupuk dan dikembangkan maka akan terlahir pribadi Muslim yang baik, yang sesuai dengan tuntutan agama. Hal ini berarti manusia membutuhkan pendidikan, pembiasaan dan pembentukan untuk mengembangkan diri dan menjadikannya manusia yang paling sempurna dengan memiliki kepribadian Muslim yang hakiki.

Alquran dan Sunnah merupakan dua pusaka Rasulullah yang harus selalu dirujuk oleh setiap Muslim dalam segala aspek kehidupan.Satu dari sekian aspek kehidupan yang amat penting adalah pembentukan dan pengembangan pribadi

${ }^{1}$ Q.S. al-Tin (95) : 4. 


\section{Ainun Mardiah Harahap}

Muslim.Pribadi Muslim yang dikehendaki oleh Alquran dan Sunnah adalah pribadi yang shaleh, pribadi yang sikap, ucapan dan tindakannya diwarnai oleh nilai-nilai yang datang dari Allah SWT. Persepsi masyarakat tentang pribadi Muslim memang berbeda-beda, bahkan banyak yang pemahamannya sempit sehingga seolah-olah pribadi Muslim itu tercermin pada orang yang hanya rajin menjalankan Islam dari aspek ubudiyah, padahal itu hanyalah salah satu aspek yang harus lekat pada pribadi seorang Muslim. Oleh karena itu standar pribadi Muslim yang berdasarkan Alquran dan Sunnah merupakan sesuatu yang harus dirumuskan, sehingga menjadi acuan bagi pembentukan pribadi Muslim.

Pembentukan kepribadian Muslim adalah pembentukan kepribadian yang diarahkan kepada peningkatan dan pengembangan faktor dasar (bawaan) dan faktor ajar (lingkungan), dengan berpedoman kepada nilai-nilai kelslaman.faktor dasar pengembangan dan peningkatan kemampuannya melalui bimbingan dan pembiasaan berfikir, bersikap dan bertingkah laku menurut norma-norma Islam. Sedangkan faktor ajar dilakukan dengan cara mempengaruhi individu melalui proses dan usaha membentuk kondisi yang mencerminkan pola kehidupan yang sejalan dengan norma-norma Islam seperti teladan, nasihat, anjuran, ganjaran, pembiasaan, hukuman, dan pembentukan lingkungan serasi.

Kepribadian Muslim di zaman sekarang ini dapat dikatakan jauh dari normanorma Islam.Hal ini dapat dibuktikan dengan maraknya korupsi di kalangan pejabat, tradisi tawuran di kalangan pelajar, buruknya silaturrahmi di kalangan masyarakat, yang semua ini tidak mencerminkan pribadi seorang Muslim.

Oleh karena itu, perlu dikaji, bagaimana sebenarnya Rasulullah SAW mendidik generasi Muslim awal sehingga mereka memiliki kepribadian yang tangguh dan mulia, yakni pribadi yang mau, mampu dan rela menegakkan kebenaran. Hal ini perlu dikaji lebih mendalam tentang Pembentukan Kepribadian Muslim dalam Perspektif Kajian Filsafat Pendidikan Islam. 


\section{Ainun Mardiah Harahap}

\section{Pembahasan}

\section{a. Pengertian Kepribadian Muslim}

Kepribadian Muslim terdiri dari dua kata, yaitu "kepribadian" dan "Muslim". Kata "kepribadian" dalam bahasa arab diistilahkan dengan al-Syakhsiyah, yang berarti kepribadian.2Dalam Kamus Besar Bahasa Indonesia kata kepribadian diartikan dengan sifat hakiki yang tercermin pada sikap seseorang atau suatu bangsa yang membedakannya dengan orang atau bangsa lain. ${ }^{3}$ Jadi kepribadian merupakan suatu hal yang urgen dimiliki oleh setiap manusia.Kepribadian adalah suatu tampilan sikap pribadi atau ciri khas yang dimiliki oleh seseorang atau bangsa.

Istilah kepribadian merupakan terjemahan dari personality (bahasa Inggris), sedangkan dalam bahasa latin kepribadian disebut dengan persona yang mempunyai arti kedok atau topeng, yang berarti tutup muka yang biasa dipakai oleh pemain-pemain panggung untuk mengambarkan perilaku, watak, atau pribadi seseorang. ${ }^{4}$ Sedangkan menurut Allport sebagaimana yang dikutip oleh H.M Arifin mendefinisikan kepribadian dengan susunan yang dinamis di dalam sistem psikofisik (jasmani-rohani) seseorang atau individu yang menentukan perilaku dan pikiran yang berciri khusus. ${ }^{5}$

Menurut Ahmad D. Marimba, kepribadian itu meliputi kwalitet keseluruhan dari seseorang. Kwalitet itu akan tampak dalam cara-cara berbuat, berfikir, berpendapat, bersikap, menyalurkan minat, filsafat hidup, serta kepercayaan. ${ }^{6}$

${ }^{2}$ Ahmad Warson Munawwir, al-Munawwir Kamus Arab-Indonesia, Cet. 14 (Surabaya: Pustaka Progressif, 1997), hlm. 701.

3Tim Penyusun Kamus Pusat Bahasa, Kamus Besar Bahasa Indonesia( Jakarta: Balai Pustaka, 2001), hlm. 895.

${ }^{4}$ Agus Suyanto, dkk., Psikologi Kepribadian (Jakarta: Aksara, 1986), hlm. 10.

5H.M. Arifin, Filsafat Pendidikan Islam (Jakarta: Bumi Aksara, 1991), hlm. 166.

${ }^{6}$ Ahmad D. Marimba, Pengantar Filsafat Pendidikan Islam (Bandung: Al-Ma'arif, 1987), hlm. 67. 


\section{Ainun Mardiah Harahap}

Abu Ahmadi dan Nur Uhbiyati mendefinisikan kepribadian Muslim sebagai kepribadian yang memiliki nilai-nilai agama Islam, memilih dan memutuskan serta berbuat berdasarkan nilai-nilai Islam dan bertanggung jawab sesuai dengan nilai-nilai Islam. ${ }^{7}$ Hal yang senada juga diungkapkan oleh M. Atiyah al-Abrasyi bahwa kepribadian Muslim adalah kepribadian yang seluruh aspek-aspeknya yakni baik tingkah laku luarnya kegiatan-kegiatan jiwanya maupun filsafat hidup dan kepercayaannya menunjukkan pengabdian kepada Tuhan, penyerahan diri kepadanya. ${ }^{8}$

Berdasarkan beberapa pendapat para ahli tentang pengertian kepribadian di atas dapat digambarkan bahwa kepribadian seseorang memiliki skup (ruang batas) yang lebih luas daripada sekedar karakter ataupun temperamen yang ada dalam diri seseorang.Di samping itu setiap orang mempunyai perilaku lahiriyah dan ruhaniyah yang berbeda-beda antara satu dengan lainnya. Kepribadian bisa terbentuk melalui perpaduan antara faktor dasar (fitrah) dan faktor ajar (lingkungan atau pendidikan) yang dialami oleh manusia, dan hal itu akan memberikan corak khusus pada kepribadian seseorang.

Menurut Jalaluddin pembentukan kepribadian Muslim sebagai individu pada dasarnya adalah; " pembentukan pribadi yang diarahkan pada pembentukan pandangan hidup yang mantap yang didasarkan pada nilainilai Islam"9Dengan demikian maka seseorang yang memiliki pandangan hidup yang sesuai dengan konsep Islam adalah merupakan individu yang telah memiliki kepribadian Muslim yang utuh. Hal tersebut berarti bahwa seluruh individu diarahkan pada pembentukan pribadi dan memiliki pandangan hidup yang sama walaupun memiliki faktor bawaan yang berbeda.

Dalam pembahasan mengenai teori kepribadian, banyak ditemukan beberapa definisi yang memberikan gambaran lebih luas tentang kepribadian itu.

${ }^{7}$ Abu Ahmadi dan Nur Uhbiyati, IImu Pendidikan (Jakarta: Rineka Cipta, 2003), hlm. 111.

${ }^{8}$ M. Atiyah Al-Abrasyi, Dasar-dasar Pokok Pendidikan Islam (Jakarta: Bulan Bintang, 1970), hlm. 73.

9Jalaluddin, Teologi Pendidikan, Cet / (Jakarta: Raja Grafindo Persada, tt), hlm. 171

Studi Multidisipliner Volume 6 Edisi 12019 M/ 1440 H 50 


\section{Ainun Mardiah Harahap}

Akan tetapi dalam konteks kepribadian Muslim maka kepribadian dapat diidentikkan dengan identitas yang dimiliki seseorang sebagai ciri khas keseluruhan sebagai seorang Muslim baik yang ditampilkan dalam tingkah laku lahiriyah maupun tingkah laku batiniyah. Islam memandang bahwa kepribadian seseorang adalah merupakan fitrah hingga setiap orang dituntut untuk menampilkan kepribadian tersebut sesuai dengan tuntunan ajaran agama Islam.

Kepribadian sangat perlu dibahas dalam kajian filsafat pendidikan Islam.Karena kepribadian manusia dalam pendidikan Islam menjadi sesuatu yang sangat penting. Kepribadian Muslim inilah yang merupakan ciri-ciri khas pada seseorang manusia yang beragama Islam yang merupakan hasil dari proses pendidikan Islam, sehingga menjadi manusia Muslim dengan kepribadian yang baik.

Dengan demikian, kepribadian Muslim adalah kepribadian seseorang yang sesuai dengan tuntunan ajaran Islam.Kepribadian yang cerminan tingkah laku dan perbuatannya sesuai dengan tuntunan yang telah digariskan dalam Islam.Kepribadian Muslim adalah kepribadian yang patuh dan berserah diri kepada Allah SWT.

\section{b. Aspek dan Tenaga Kepribadian Muslim}

Kepribadian sebagai kwalitet keseluruhan yang kompleks dari seseorang yang membedakan satu orang dengan orang lain, menjadikan kepribadian setiap orang tidak ada yang sama persis. Perbedaan kepribadian tersebut terletak pada kualitas aspek dan tenaga kepribadian yang dimiliki masing-masing orang.

Dalam perspektif Islam, pemahaman yang benar tentang makna kepribadian Islami harus mengacu kepada konsepsi Islam tentang manusia.Dalam Alquran dijelaskan bahwa manusia diciptakan dari unsur-unsur yang bersifat fisik-materi dan non fisik- non materi. Karenanya manusia merupakan makhluk dwi dimensi. Dimensi fisik- 
Ainun Mardiah Harahap

materi manusia adalah al-Jism dan dimensi non fisik- non materi adalah al-Ruh. 10

Dari kutipan di atas dapat dipahami bahwa manusia memiliki potensi yang siap dibentuk menjadi kepribadian yang Islami. Hal ini berarti potensi manusia tersebut baik yang bersifat materi dan non materi bisa dikembangkan dengan faktor ajar atau dengan proses latihan dan pendidikan.

Adapun aspek-aspek kepribadian seseorang dapat diklasifikasikan sebagai berikut:

1. Aspek-aspek kejasmanian, meliputi tingkah laku luar yang tampak dari luar, misalnya cara-cara berbuat, berbicara dan sebagainya.

2. Aspek-aspek Kejiwaan, meliputi aspek-aspek yang tidak segera dapat dilihat atau ketahuan dari luar.

3. Aspek-aspek keruhanian yang luhur, meliputi aspek-aspek kejiwaan yang lebih abstrak. ${ }^{11}$

Hal yang senada dengan pendapat di atas Harun Nasution sebagaimana yang dikutip oleh Al Rasyidin menambahkan bahwa dimensi materi manusia (alJism) memiliki: Pertama, daya-daya fisik atau jasmani seperti mendengar, melihat, merasa, mencium dan sebaginya. Kedua, daya gerak seperti kemampuan untuk menggerakkan tangan, kepala, kaki dan sebagainya dan kemampuan untuk berpindah tempat.Sementara itu dimensi non-materi (al-Ruh) memiliki: Pertama, daya berfikir atau kemampuan melakukan penalaran yang disebut al-Aq/ yang berpusat di kepala, Kedua, daya merasa dan memahami yang disebut al-Qalb yang berpusat di dada, dan Ketiga, daya jiwa yang disebut al-Nafs dan berpusat di perut. 12

${ }^{10} \mathrm{Al}$ Rasyidin, Falsafah Pendidikan Islami: Membangun Kerangka Ontologi, Epistimologi, dan Aksiologi Praktik Pendidikan, Cet. 1 (Bandung: Citapustaka Media Perintis, 2008), hlm. 82.

${ }^{11}$ Abd. Haris, Filsafat Pendidikan Islam (Jakarta: Amzah, 2012), hlm. 102.

${ }_{12}$ Harun Nasution, Islam Rasional (Bandung: Mizan, 1995), hlm. 37.

Studi Multidisipliner Volume 6 Edisi 12019 M/ $1440 \mathrm{H}$ 


\section{Ainun Mardiah Harahap}

Dari keterangan di atas dapat dipahami bahwa aspek kepribadian Muslim terdiri atas aspek materi atau fisik dan non materi atau non fisik.kedua aspek ini saling berkaitan satu dengan yang lainnya. Dengan kedua aspek tersebut akan melahirkan nilai-nilai yang dapat meresap ke dalam kepribadian seseorang dan telah menjadi bagian yang mendarah daging dalam kepribadian, serta mengarahkan dan memberi corak pada seluruh kehidupan seseorang. Bagi orang-orang yang beragama, aspek aspek ini menuntunnya ke arah kebahagiaan, bukan saja di dunia tetapi juga di akhirat.Aspek-aspek ini memberi warna bagi kwalitet kepribadian seorang Muslim secara keseluruhan.

Karakter dasar atau natur al-Ruh adalah suci dan cenderung pada dimensi spritualitas, sebab ia memang berasal dari alam suci yang Maha Tinggi (alam Ilahiyah). Sedangkan karakter dasar al-Jism adalah rendah dan cenderung pada materi, sebab ia berasal dari alam yang rendah. ${ }^{13}$ Sebagaimana firman Allah SWT dalam surah al-Hijr ayat 29 sebagai berikut:

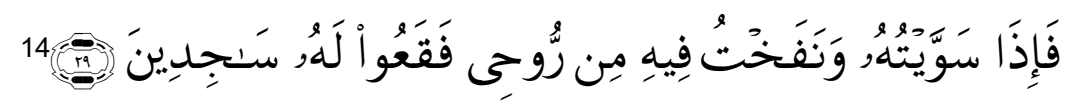

Artinya: Maka apabila telah Kusempurnakan kejadiannya dan Kutiupkan kepadanya roh (ciptaan)Ku; Maka hendaklah kamu tersungkur dengan bersujud kepadaNya.

Dari ayat di atas perlu digaris bawahi adalah kata " wa nafakhtu fihi min ruhi". dapat dipahami bahwa ruh yang dimiliki manusia adalah berasal dari Allah SWT, dengan konsekuensi al-Ruh akan kembali kepada Allah di saat ruh berpisah dari al-Jism manusia. Selanjutnya dapat dilihat ayat dalam surat alAn'am ayat 2 berikut ini:

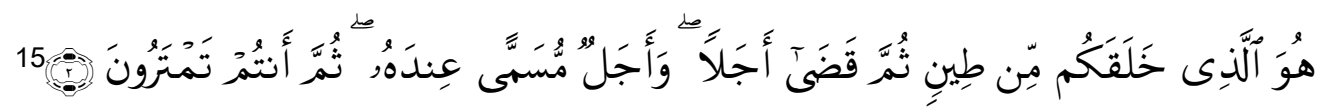

${ }^{13} \mathrm{Al}$ Rasyidin, Falsafah Pendidikan Islami., hlm. 83.

${ }^{14}$ Q.S. al-Hijr (15): 29.

Studi Multidisipliner Volume 6 Edisi 12019 M/ 1440 H 53 


\section{Ainun Mardiah Harahap}

Artinta: Dialah yang menciptakan kamu dari tanah, sesudah itu ditentukannya ajal (kematianmu), dan ada lagi suatu ajal yang ada pada sisi-Nya (yang Dia sendirilah mengetahuinya), kemudian kamu masih ragu-ragu (tentang berbangkit itu).

Ayat ini menjelaskan bahwa al-Jism yang dimiliki oleh manusia berasal dari tanah, yaitu tempat yang rendah dan identik dengan kotor dalam pemahaman manusia.

Ali Syari'ati sebagaimana dikutip oleh Ramayulis senada dengan pendapat Al Rasyidin di atas menjelaskan bahwa ruh yang ditiupkan kepada manusia adalah The Spirit Of God (Ruh llahi). Ruh ini bersifat metafisis dan dinamis.Dengan sifatnya yang dinamis memungkinkan manusia meraih derajat setinggi-tingginya, atau menjerumuskannya pada derajat yang serendahrendahnya. Manusia memiliki kehendak bebas (The Freedom Of Will) untuk mendekatkan diri ke kutub "ruh ilahi" atau kekutub "tanah". 16

Dari keterangan ayat di atas dapat disimpulkan bahwa dalam proses pembentukan kepribadian Muslim dengan aspek al-Jism dan al-Ruh membutuhkan tenaga-tenaga atau daya untuk mengaktualisasikan kepribadian Muslim tersebut. Adapun tenaga-tenaga kepribadian tersebut bisa dilihat di bawah ini:

1. Tenaga-tenaga kejasmanian, meliputi tenaga-tenaga yang bersumber dari tubuh, misalnya tenaga-tenaga yang bersumber dari kelenjarkelenjar, peredaran darah, alat-alat pernafasan, syaraf dan sejenisnya.

2. Tenaga-tenaga kejiwaan, terdiri dari karsa, rasa dan cipta. Tenagatenaga kejiwaan juga terdiri atas syahwat, ghadab dan natiqah.

3. Tenaga keruhanian yang luhur. Tenaga ini disebut dengan Qalbu.17

${ }^{15}$ Q.S. al-An'am (6): 2.

${ }^{16}$ Ramayulis, Metodologi Pendidikan Agama Islam (Jakarta: Kalam Mulia, 2008), hIm. 75.

${ }_{17}$ Marimba, Pengantar...., hlm. 69-71.

Studi Multidisipliner Volume 6 Edisi 12019 M/ 1440 H 54 


\section{Ainun Mardiah Harahap}

Tenaga kepribadian di atas dapat mempengaruhi terbentuknya aspekaspek kejasmanian dan pada batas-batas tertentu mempengaruhi aspek-aspek kejiwaan dan kepribadian.

Dalam menerapkan tenaga-tenaga tersebut di atas, al-Ruh membutuhkan al-Jismsehingga lahir dan muncul tingkah laku.Dari sisi ini dapat dinyatakan bahwa al-Jismmerupakan wahana bagi al-Ruh untuk mengaktualisasikan seluruh keinginan atau kehendaknya.Aktualisasi daya-daya al-Ruh yakni nafs, qalb, dan 'aq/ merupakan citra kepribadian seseorang.Wujud nyata aktualisasi tersebut adalah pola pikir (mafahim), pola rasa (Zawq), pola tingkah laku ('amal) dan pola 'ibadah yang dapat dikarakteristikkan secara konsisten dilakukan seseorang.Karenanya, dari sisi ini, al-Ruhmemiliki peran sangat menentukan dalam membentuk kepribadian; al-Ruh lah yang mengarahkan manusia untuk memilih dan melakukan suatu perilaku dan tindakan.Melalui al-'Aql, al-Ruh memberi daya dan mendorong manusia untuk melakukan penalaran dan pemahaman, al-Nafs untuk mengatur dan mengendalikan diri, dan al-Qalb untuk melakukan dan meraih pencerahan diri. ${ }^{18}$

Dengan demikian, tenaga dalam pembentukan kepribadian Muslim al-Jism dan al-Ruhdua unsur yang saling mendukung satu sama lain. al-Ruh tidak dapat diwujudkan tanpa adanya al-Jism, sehingga memunculkan tingkah laku. Kualitas suatu perilaku manusia sangat bergantung kepada unsur-unsur yang membentuk kepribadiannya.Ketika al-Ruh cenderung mengikatkan diri dan terperangkap oleh alam materi, maka tingkah laku yang ditampilkan seseorang adalah tingkah laku yang rendah.Sebaliknya, jika al-Ruh cenderung dan berorientasi pada naturnya, maka perilaku yang ditampilkan adalah tingkah laku yang mulia.

${ }^{18}$ Al Rasyidin, Falsafah...., hlm. 84. 


\section{Ainun Mardiah Harahap}

\section{c. Faktor yang Mempengaruhi Kepribadian Muslim}

Kepribadian seseorang itu dipengaruhi oleh dua faktor.Pertama, faktor pembawaan, yaitu potensi yang dibawa seseorang sejak lahir, baik dalam bentuk fisik dan non fisik.Kedua, faktor lingkungan yaitu segala sesuatu di luar potensi yang dibawa sejak lahir. ${ }^{19}$

Potensi bawaan manusia adalah potensi yang memerlukan pendidikan dan pembiasaan, membiarkan potensi bawaan tumbuh secara alamiah tanpa bantuan pendidikan sangat memungkinkannya kehilangan arah dalam menempuh perjalanan menuju kebaikan dan kebenaran.

Menurut Ali Syari'ati, ada beberapa faktor yang dapat mempengaruhi proses pembentukan kepribadian seseorang, yaitu:

1. Faktor ibu yang memberi struktur dan dimensi keruhanian yang penuh dengan kasih sayang dan kelembutan.

2. Faktor ayah yang memberikan dimensi kekuatan dan harga diri.

3. Faktor sekolah yang membantu terbentuknya sifat lahiriyah.

4. Faktor masyarakat dan lingkungan yang memberikan lingkungan empiris.

5. Faktor kebudayaan umum dan masyarakat yang memberikan corak pada kehidupan manusia. 20

Dari kutipan di atas dapat dipahami bahwa faktor individu sangat mempengaruhi faktor masyarakat pada umumnya. Ibu dan ayah ataupun keluarga adalah lembaga pendidikan yang pertama dan utama dalam proses pendidikan dan pembentukan kepribadian yang Islami. Pembentukan kepribadian Muslim dari setiap individu akan membangun suatu bentuk kepribadian ummah dalam suatu komunitas masyarakat yang berkepribadian Islami.

Menurut Marcel A. Boesard, ada tiga aspek pokok yang memberi corak khusus bagi kepribadian seseorang: Pertama, adanya wahyu Tuhan yang memberi ketetapan kewajiban pokok yang harus dilaksanakan seorang Muslim.

19Haris, Filsafat Pendidikan Islam..., hlm. 100.

20 Ali Syari'ati, Sosiologi Islam (Yogyakarta: Ananda, 1982), hlm. 63-64.

Studi Multidisipliner Volume 6 Edisi 12019 M/ 1440 H 56 


\section{Ainun Mardiah Harahap}

Kedua, praktik ibadah yang harus dilaksanakan dengan aturan-aturan yang pasti dan teliti.Ketiga, konsep Alquran tentang alam yang menggambarkan penciptaan manusia secara harmonis dan seimbang. ${ }^{21}$

Hal yang sama dengan ungkapan di atas menurut al-Nabhani sebagaimana yang dikutip oleh Al Rasyidin bahwa perilaku yang ditampilkan seseorang itu dilatari oleh dua faktor utama. Pertama, persepsi atau pemahaman yang ada pada seseorang sebagai hasil proses berfikirnya terhadap suatu fakta. Kedua, Kecenderungan yang terdapat dalam jiwa seseorang terhadap suatu fakta. Faktor pertama berhubungan dengan aktivitas intelektual atau penalaran terhadap fakta, dan faktor kedua berkaitan dengan sikap jiwa manusia, yaitu cara seseorang berbuat untuk memuaskan segala kebutuhan dan keinginannya, yang dicirikan oleh adanya kecenderungan-kecenderungan terhadap sesuatu. ${ }^{22}$

Dengan demikian, jelas bahwa kepribadian Muslim itu dipengaruhi oleh faktor dasar (potensi) manusia dan faktor ajar (lingkungan) yang melingkupinya, terutama ajaran agama Islam.

\section{d. Proses Pembentukan Kepribadian Muslim}

Manusia adalah makhluk yang berketuhanan atau disebut Homodivinous (makhluk yang percaya adanya Tuhan) atau disebut juga Homoreligious artinya makhluk yang beragama. ${ }^{23}$

Dalam pandangan Islam, sejak lahir manusia telah mempunyai jiwa agama, jiwa yang mengakui adanya zat yang Maha Pencipta dan Maha Mutlak yaitu Allah SWT.Sejak di dalam ruh, manusia telah mempunyai komitmen bahwa Allah adalah Tuhannya. Pandangan ini bersumber dari firman Allah SWT dalam surat al-A'raf ayat 172, yaitu:

${ }^{21}$ H.M. Rasyidi, Humanisme dalam Islam (Jakarta: Bulan Bintang, 1980), hlm. 157.

22Al Rasyidin, Falsafah ...., hlm. 81-82.

23Ramayulis, Metodologi...., hlm. 71. 
Ainun Mardiah Harahap

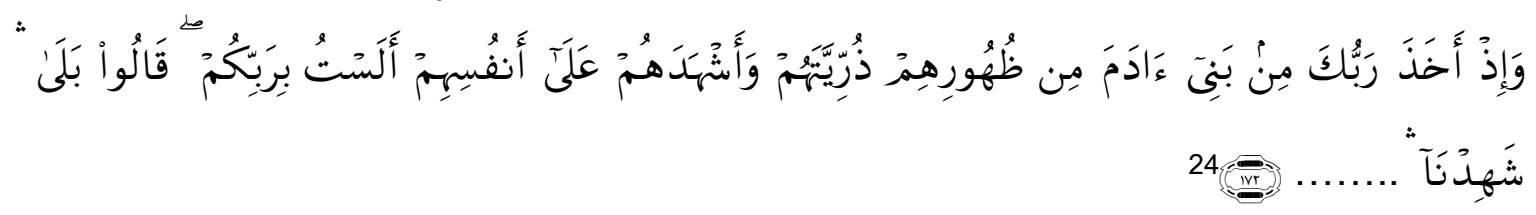

Artinya: dan (ingatlah), ketika Tuhanmu mengeluarkan keturunan anak-anak Adam dari sulbi mereka dan Allah mengambil kesaksian terhadap jiwa mereka (seraya berfirman): "Bukankah aku ini Tuhanmu?" mereka menjawab: "Betul (Engkau Tuhan kami), Kami menjadi saksi".....

Kepribadian tidak dapat dibentuk hanya dalam waktu sekejap, tetapi memerlukan proses dalam waktu yang relatif panjang dan berangsur-angsur. Ada tahapan-tahapan yang harus dilalui dengan memperhatikan semua aspekaspek dan tenaga kepribadian, sehingga pembentukan kepribadian bisa berhasil dan terwujud.

Adapun tahapan yang dilakukan dalam proses pembentukan kepribadian Muslim adalah sebagai berikut:

\section{Tazkiyah Al-Nafs}

Dalam upaya membentuk pribadi-pribadi yang teguh pada syahadah primordialnya Rasulullah tidak langsung men-ta'lim, men-Tarbiyah men-ta'dib umatnya. Proses pendidikan yang dilalui beliau menjadi cermin baginya dalam mendidik umatnya. Dengan kejadian pembelahan dan pembersihan hati beliau, kemudian diisi dengan ilmu dan keimanan, seringnya beliau mengasingkan diri di gua hira dengan tujuan untuk mensucikan diri dan menghindar dari pengaruh negatif kemaksiatan. Tentunya semua itu bertujuan untuk proses Tazkiyah alNafs yang mengantarkan beliau pada kondisi siap untuk di-ta'lim di-tarbiyah dan di-ta'dib Allah SWT. 25

${ }^{24}$ Q.S. al-A'raf (7): 172.

${ }^{25} \mathrm{Al}$ Rasyidin, Falsafah ...., hlm. 86-87.

Studi Multidisipliner Volume 6 Edisi 12019 M/ $1440 \mathrm{H}$ 


\section{Ainun Mardiah Harahap}

Berdasarkan keterangan di atas dapat disimpulkan bahwa proses pendidikan dalam membentuk kepribadian Muslim yang sebenarnya harus diawali dengan proses Tazkiyah al-Nafs, yaitu proses pensucian diri dan hati manusia dari segala kotoran, penyakit, dan sebagainya. Dengan demikian ilmu atau pendidikan dapat dilakukan dengan mudah, sebab manusia tersebut telah bersih dan sehat dari berbagai bentuk kotoran dan penyakit.

Dalam Islam al-'Ilm harus di-ta'lim, di-tarbiyah atau di-ta'dibkan ke dalam diri agar menjadi kepribadian seorang Muslim adalah al-Nur (cahaya, kebenaran, hidayah Allah). Agar al-Nur, al-Haq atau al-Huda tersebut tertanam dan bersemi dalam diri seseorang Muslim sehingga terbentuk kepribadian Islami, maka nafs, qalb, 'aq/dan jasad-nya harus terlebih dahulu di-tazkiyah (dibersihkan atau disucikan).Sebab cahaya, kebenaran atau hidayah Allah SWT mustahil dapat ditanamkan dan bersemi dalam diri dan menghantarkan seseorang pada kepribadian Islami, manakala nafs, qalb, 'aql, dan jasad-nya masih kotor atau dicemari oleh dosa dan maksiat. Karenanya, langkah pertama yang harus dilakukan dalam proses pembentukan kepribadian Islami (takwin al-Syakhsiyah al-Islamiyah) adalah pensucian (tazkiyah) ruh dan jasad dari berbagai sifat dan perilaku maksiat, baru kemudian pengisian nafs, qalb, dan 'aq/ dengan keimanan dan $a l-i / m$ ('aqidah wa al-nur). ${ }^{26}$

Berdasarkan keterangan di atas, langkah yang pertama dan utama dalam proses pembentukan kepribadian Muslim adalah Tazkiyah al-Nafs yaitu pensucian diri dari segala kotoran dan kemaksiatan, karena ilmu Allah dilambangkan dengan al-Nur dan al-Nur Allah tidak akan dapat bersemi di hati dan diri manusia yang penuh dengan kemaksiatan.

${ }^{26}$ Al Rasyidin, Falsafah...., hlm. 87-88. 


\section{Ainun Mardiah Harahap}

\section{Proses Pembiasaan}

Pembiasaan ini dilakukan untuk melatih keterampilan aspek-aspek jasmaniah yang berkaitan dengan kecakapan berbuat dan mengucapkan sesuatu, misalnya pembiasaan shalat lima waktu yang dapat dikontrol, baik gerakan-gerakan maupun bacaan-bacaan yang dilakukan. Dengan pembiasaan, akan diperoleh hasil yang sesuai dengan yang diharapkan, misalnya anak akan melakukan shalat dengan gerakan dan bacaan yang benar. Jadi, tujuan utama dari pembiasaan ini adalah menanamkan kecakapan-kecakapan berbuat dan mengucapkan sesuatu, agar cara-cara yang tepat dapat dikuasai dengan baik. ${ }^{27}$

Dalam rangka pembiasaan, diperlukan alat-alat yang berkaitan dengan pembentukan kepribadian, antara lain:

a. Alat-alat langsung, yaitu alat-alat yang segaris dan searah dengan maksud pembentukan, misalnya teladan, anjuran, perintah, latihan-latihan, hadiahhadiah kompetisi dan sebagainya.

b. Alat-alat tidak langsung, bersifat mencegah dan menekan hal-hal yang akan merugikan maksud pembentukan, misalnya koreksi dan pengawasan, larangan-larangan, hukuman dan sebagainya. ${ }^{28}$

Pembiasaan ini tepat dilakukan pada masa anak-anak (usia 0 - 2 tahun), masa kanak-kanak (2 - 7 tahun), separuh masa sekolah (7 - 13 tahun), dan seterusnya. ${ }^{29}$ Pada masa anak-anak dan kanak-kanak dibiasakan untuk hidup teratur dan senang kebersihan, sedangkan masa sekolah (intelek) sudah dapat dibiasakan untuk shalat dan berpuasa.

${ }^{27}$ Marimba, Pengantar..., hlm. 76.

28Haris, Filsafat...., hlm. 105.

29Haris, Filsafat...., hlm. 105-106.

Studi Multidisipliner Volume 6 Edisi 12019 M/ 1440 H 60 


\section{Ainun Mardiah Harahap}

\section{Pembentukan Pengertian, Sikap dan Minat}

Pembentukan pengertian, sikap, dan minat merupakan kelanjutan dari pembiasaan dan sebagian sudah dikenalkan pada tahap pertama, yaitu tahap pembiasaan. Dengan pembentukan pengertian, apa yang sudah biasa dikerjakan dapat dipahami oleh si anak, dan dalam pembentukan pengertian ini seharusnya ditanamkan dasar-dasar kesusilaan yang berkaitan dengan masalah kepercayaan. Misalnya rukun iman dan rukun Islam harus diajarkan dengan pengertian dan pemahaman, dengan menggunaan tenaga kejiwaan. 30

Dengan pembentukan pengertian, sikap, dan minat akan diperoleh hal-hal sebagai berikut:

a. Pengertian tentang pokok-pokok pembinaan dalam amalan jiwa serta sangkut pautnya dengan amalan jasmaniah. Pengertian ini meliputi nilainilai kesusilaan, tentang apa yang baik dan benar.

b. Kecintaan kepada kebaikan dan kebencian terhadap kejahatan, sehingga akan didapatkan sesuatu yang dapat mendorong untuk mengerjakan amalan yang baik dan meninggalkan amalan yang jahat.

c. Rasa berkepentingan dalam soal-soal pelaksanaan kebaikan dan memperbesar minat kepada hal-hal yang baik, dan selanjutnya minat itu dapat mendorong pelaksanaan akan perbuatan yang telah dipahami. ${ }^{31}$

Ketiga hasil di atas akan menjurus ke arah keyakinan dengan sadar (bukan ikut-ikutan) terhadap pokok kepercayaan yang akan ditanamkan dalam pembentukan keruhanian yang luhur.

Alat-alat yang dipakai dalam tahapan pembiasaan masih dapat dipergunakan pada tahap ini, tetapi lebih ditekankan pada kesadaran sang anak itu sendiri.

Pada tahap kedua ini dititikberatkan pada perkembangan akal, minat, dan sikap (pendirian) dengan tiga jalur pembentukan, yaitu:

30Marimba, Pengantar...., hlm. 77.

31Haris, Filsafat...., hlm. 106-107.

Studi Multidisipliner Volume 6 Edisi 12019 M/ 1440 H 61 


\section{Ainun Mardiah Harahap}

a. Pembentukan formil, yaitu pembentukan yang dilaksanakan dengan latihan-latihan cara berfikir yang baik, penanaman minat yang kuat, dan sikap (pendirian yang tepat).

b. Pembentukan materil, yaitu pembentukan yang berkenaan dengan pemberian ilmu pengetahuan, misalnya, ilmu-ilmu duniawi, ilmu-ilmu kesusilaan, ilmu-ilmu keagamaan, dan lain sebagainya.

c. Pembentukan intensil, yaitu pembentukan yang berupa pengarahan. Dalam pendidikan Islam pengarahan itu sudah jelas, yaitu kea rah terbentuknya kepribadian Muslim. ${ }^{32}$

Pembentukan pengertian, sikap dan minat ini dilaksanakan pada masa sekolah (umur 7-13 tahun), masa remaja (umur 13-21 tahun), masa permulaan dewasa (umur 21 tahun), dan seterusnya.Anak-anak biasanya sanggup menerima pengertian terutama yang berhubungan dengan kebiasaankebiasaannya pada level pertama.Pengetahuan keagamaan, nilai-nilai kemasyarakatan, dan kesusilaan dapat dipahamkan secara berangsur-angsur. Semua ini akan membantu dalam perkembangan kepribadian seseorang di masa dewasa.

\section{Pembentukan Keruhanian yang Luhur}

Pembentukan keruhanan yang luhur ini dilakukan dengan menggunakan tenaga budi dan tenaga-tenaga kejiwaan yang lain sebagai tambahan. Dengan pembentukan keruhanian yang luhur, akan dihasilkan kesadaran dan pengertian yang mendalam. Dengan pembentukan ini, segala yang ada dalam pikiran seseorang yang dipilih dan diputuskannya, serta yang dilakukannya, adalah berdasarkan keinsafan sendiri dan dilakukan dengan penuh rasa tanggung jawab.

Pada tahap ini proses yang ada tepat disebutkan dengan "pendidikan diri sendiri" Budi menjadi tenaga yang sangat diperlukan dalam pembentukan tahap ini. Budi yang dapat bekerja dengan baik akan mengarahkan akal dan menekan

32Haris, Filsafat...., hlm. 107. 


\section{Ainun Mardiah Harahap}

tenaga-tenaga yang lebih rendah. Apabila budi seseorang bekerja dengan baik maka hasil yang akan diperoleh adalah kepribadian yang sempurna. ${ }^{33}$

Masa yang tepat untuk pembentukan kepribadian keruhanian yang luhur adalah masa dewasa sampai pada masa kesempurnaan.Sesuatu yang dapat ditanamkan pada masa ini adalah kepercayaan yang terdiri dari rukun iman yang enam, sebagaimana yang diajarkan oleh Islam.

\section{Kesimpulan}

Berdasarkan pembahasan tentang Pembentukan Kepribadian Muslim dalam Perspektif Filsafat Pendidikan Islam di atas, dapat dirumuskan beberapa kesimpulan, antara lain:

1. Kepribadian Muslim sebagai kepribadian yang memiliki nilai-nilai agama Islam, memilih dan memutuskan serta berbuat berdasarkan nilai-nilai Islam dan bertanggung jawab sesuai dengan nilai-nilai Islam.

2. Aspek kepribadian Muslim terdiri atas aspek materi atau fisik dan non materi atau non fisik. kedua aspek ini saling berkaitan satu dengan yang lainnya. Dengan kedua aspek tersebut akan melahirkan nilai-nilai yang dapat meresap ke dalam kepribadian seseorang dan telah menjadi bagian yang mendarah daging dalam kepribadian, serta mengarahkan dan memberi corak pada seluruh kehidupan seseorang.

3. Ada beberapa faktor yang dapat mempengaruhi proses pembentukan kepribadian seseorang, yaitu: Pertama, faktor ibu yang memberi struktur dan dimensi keruhanian yang penuh dengan kasih sayang dan kelembutan.Kedua, faktor ayah yang memberikan dimensi kekuatan dan harga diri.Ketiga, faktor sekolah yang membantu terbentuknya sifat lahiriyah.Keempat, faktor masyarakat dan lingkungan yang memberikan

33Marimba, Pengantar..., hlm. 80. 


\section{Ainun Mardiah Harahap}

lingkungan empiris.Kelima, faktor kebudayaan umum dan masyarakat yang memberikan corak pada kehidupan manusia.

4. Proses pendidikan dalam membentuk kepribadian Muslim yang sebenarnya harus diawali dengan proses Tazkiyah al-Nafs, yaitu proses pensucian diri dan hati manusia dari segala kotoran, penyakit, dan sebagainya.

\section{Daftar Pustaka}

Abd. Haris, Filsafat Pendidikan Islam, Jakarta: Amzah, 2012.

Agus Suyanto, dkk., Psikologi Kepribadian, Jakarta: Aksara, 1986.

Ahmad D. Marimba, Pengantar Filsafat Pendidikan Islam, Bandung: Al-Ma'arif, 1987.

Ahmad Warson Munawwir, al-Munawwir Kamus Arab-Indonesia,Surabaya:

Pustaka Progressif, 1997.

Al Rasyidin, Falsafah Pendidikan Islami: Membangun Kerangka Ontologi, Epistimologi, dan Aksiologi Praktik Pendidikan,Bandung: Citapustaka Media Perintis, 2008.

Ali Syari'ati, Sosiologi Islam, Yogyakarta: Ananda, 1982.

H.M. Arifin, Filsafat Pendidikan Islam, Jakarta: Bumi Aksara, 1991.

H.M. Rasyidi, Humanisme dalam Islam, Jakarta: Bulan Bintang, 1980.

Harun Nasution, Islam Rasional, Bandung: Mizan, 1995.

Jalaluddin, Teologi Pendidikan, Jakarta, Raja Grafindo Persada, tt.

Ramayulis, Metodologi Pendidikan Agama Islam, Jakarta: Kalam Mulia, 2008.

Tim Penyusun Kamus Pusat Bahasa, Kamus Besar Bahasa Indonesia, Jakarta:

Balai Pustaka, 2001. 